\title{
PELO wt Allele
}

National Cancer Institute

\section{Source}

National Cancer Institute. PELO wt Allele. NCI Thesaurus. Code C104582.

Human PELO wild-type allele is located in the vicinity of $5 q 11.2$ and is approximately $16 \mathrm{~kb}$ in length. This allele, which encodes protein pelota homolog, may play a role in RNA degradation and cell division. 